\title{
FREQUENCY FOLLOWING RESPONSE AND MUSICAL EXPERIENCE: A REVIEW
}

Contributions: A Study design/planning B Data collection/entry C Data analysis/statistics D Data interpretation E Preparation of manuscript E Literature analysis/search $\mathrm{G}$ Funds collection

\section{Madel Valle Rodrigues ${ }^{1 A B C E F}$, Caroline Donadon ${ }^{2 B C D E F}$, Mariana Guedes-Weber ${ }^{1 \mathrm{~A}}$, Sandra Giorgi Sant'anna ${ }^{1 \mathrm{~A}}$, Piotr H. Skarzynski, ${ }^{3,4,5 A E G}$, Stavros Hatzopoulos ${ }^{6 A G}$, Maria Francisca Colella-Santos ${ }^{2 E}$, Milaine Dominici Sanfins ${ }^{1,2 A B C D E F}$}

\author{
${ }^{1}$ Faculty of Knowledge and Science, Amazon, Brazil \\ ${ }^{2}$ Child and Adolescent Heath Program, Faculty of Medical Sciences, State University of \\ Campinas, Campinas, São Paulo, Brazil \\ ${ }^{3}$ Department of Teleaudiology and Screening, World Hearing Center, Institute of \\ Physiology and Pathology of Hearing, Warsaw, Poland \\ ${ }^{4}$ Department of Heart Failure and Cardiac Rehabilitation, Medical University of Warsaw, \\ Poland \\ ${ }^{5}$ Institute of Sensory Organs, Warsaw, Poland \\ ${ }^{6}$ Audiology and ENT Clinic, University of Ferrara - UNIFE, Ferrara, Italy \\ Corresponding author: Milaine Dominici Sanfins, Faculty of Medical Science - State \\ University of Campinas (UNICAMP). Rua Jacutinga, 220 - apto 12, Moema, São Paulo, \\ Brazil. CEP: 04515-030, Telephone: +55 11 97060-3838, e-mail:msanfins@uol.com.br
}

\begin{abstract}
The aim of this review is to compare published FFR studies for groups of musicians and non-musicians. Musicians are taken to be those who have used their instrument at least twice a week for many years. The review considers sample size, age, gender, native language, preliminary and complementary assessments, equipment, stimuli, objective results, and conclusions of the studies.

Medline/PubMed and Web of Science databases were accessed. Keywords were restricted to English Medical Subject Heading (MeSH) terms and included: auditory brainstem response, speech ABR, speech perception, frequency following response, musicians. The search identified 140 articles published between 2008 and 2015. After filtering the total number of papers according to inclusion and exclusion criteria, 11 studies remained.

Analysis showed that individuals with musical experience, that is, play a musical instrument at least 2 to 3 hours per week, show an improved development of their FFR. Musical experience improves a broad range of abilities: detection, recognition, and discrimination of sound stimuli are processed more accurately and effectively in musicians. The improvement also relates to the encoding of speech, facilitating literacy. Assessment by FFR allows neural changes from musical training to be monitored.
\end{abstract}

Key words: auditory brainstem response $\bullet$ musician $\bullet$ speech perception • electrophysiology $\bullet$ FFR

\section{POTENCIAL EVOCADO AUDITIVO DE SEGUIMIENTO (FFR) Y EXPERIMENTOS MUSICOS - REVISION}

\section{Resumen}

El propósito de esta revisión es comparar los estudios publicados de potencial evocado auditivo de seguimiento (FFR, por sus siglas en inglés) en grupos de músicos y no músicos. En este trabajo, se define como músico a toda persona que toca un instrumento musical al menos dos veces por semana durante diversos años. La revisión tuvo en cuenta el tamaño de la muestra, la edad, el sexo y la lengua materna, la evaluación inicial y de seguimiento, el equipo, el estímulo, los resultados objetivos y las conclusiones del estudio.

El análisis se basó en las bases de datos Medline / PubMed y Web of Science. Las palabras clave se limitaron al inglés según los principios de Medical Subject Heading (MeSH), que incluyen: potenciales auditivos evocados del tronco cerebral, habla ABR, percepción del habla, potenciales evocados, músicos. Se encontraron 140 artículos publicados entre los años 2008 y 2015 . Luego de filtrar todos los artículos según criterios de inclusión y exclusión, quedaron 11 trabajos.

El análisis mostró que las personas que tienen experiencia musical, es decir, que tocan un instrumento musical al menos dos o tres horas a la semana, muestran un mejor desarrollo de la FFR. La experiencia musical tiene un efecto positivo en muchas habilidades: los músicos tienen una detección, un reconocimiento y una diferenciación de los estímulos sonoros más desarrollados y efectivos. También se observa una mejor codificación de los sonidos del habla, lo que facilita los procesos de lectura y escritura. La evaluación de los FFR permite monitorear los cambios neuronales relacionados con la práctica musical.

Palabras clave: • potenciales evocados auditivos del tronco del encéfalo • músico • percepción del habla • electrofisiología; FFR 


\title{
ПОТЕНЦИАЛЫ ВОСПРОИЗВОДЯЩИЕ ЧАСТОТУ И МУЗЫКАЛЬНЫЙ ОПЫТ - ОБЗОР
}

\begin{abstract}
Аннотация
Целью данного обзора является сравнение опубликованных исследований потенциалов, воспроизводящих частоту (FFR), в двух группах: музыкантов и не музыкантов. В этой работе «музыкант» классифицируется как человек, который играет на музыкальном инструменте по крайней мере два раза в неделю в течение многих лет. В обзоре учитывались размер выборки, возраст, пол и родной язык, начальная и последующая оценка, оборудование, стимулы, объективные результаты и выводы исследований.

Анализ основывался на базах данных Medline / PubMed и Web of Science. Ключевые слова были ограничены английским языком в соответствии с принципами Medical Subject Heading (MeSH), в том числе: слуховые вызванные потенциалы, КСВП речи, восприятие речи, потенциалы воспроизводящие частоту, музыканты. Найдено 140 статей, опубликованных в $2008-2015$ годах. После фильтрации всех статей в соответствии с критериями включения и исключения осталось 11 работ.

Анализ показал, что люди, которые имеют музыкальный опыт, то есть играют на музыкальном инструменте не менее двухтрех часов в неделю, показывают лучшее развитие FFR. Музыкальный опыт положительно влияет на многие навыки: у музыкантов более развито и более эффективно обнаружение, распознавание и дифференциация звуковых стимулов. Также у них наблюдается более высокий уровень кодирования речевых звуков, что облегчает процессы чтения и письма. Оценка потенциалов, воспроизводящих частоту, позволяет отслеживать нейронные изменения, связанные с музыкальной деятельностью.
\end{abstract}

Ключевые слова: слуховые вызванные потенциалы головного мозга • музыкант • восприятие речи • электрофизиология • FFR

\section{CZĘSTOTLIWOŚCIOWE POTENCJAŁY WOWOŁANE I DOŚWIADCZENIE MUZYCZNE - PRZEGLĄD}

\section{Streszczenie}

Celem niniejszego przeglądu jest porównanie opublikowanych badań częstotliwościowych potencjałów wywołanych (FFR) w grupach muzyków i niemuzyków. W niniejszej pracy jako muzyka klasyfikuje się osobę, która gra na instrumencie co najmniej dwa razy w tygodniu przez wiele lat. W przeglądzie wzięto pod uwagę wielkość próby, wiek, płeć i język ojczysty, ocenę wstępną i uzupełniającą, wyposażenie, bodziec, obiektywne wyniki i wnioski z badan.

Analizę przeprowadzono w oparciu o bazy danych Medline / PubMed i Web of Science. Słowa kluczowe były ograniczone do języka angielskiego zgodnie z zasadami Medical Subject Heading (MeSH), w tym: słuchowe potencjały wywołane z pnia mózgu, ABR mowy, percepcja mowy, częstotliwościowe potencjały wywołane, muzycy. Wyszukano 140 artykułów opublikowanych w latach 2008-2015. Po przefiltrowaniu wszystkich artykułów zgodnie z kryteriami włączenia i wykluczenia, pozostało 11 prac.

Analiza pokazała, że osoby, które mają doświadczenia muzyczne, tj. grają na instrumencie muzycznym co najmniej od dwóch do trzech godzin tygodniowo, wykazują lepszy rozwój FFR. Doświadczenie muzyczne ma pozytywny wpływ na wiele umiejętności: u muzyków jest bardziej rozwinięte i skuteczniejsze wykrywanie, rozpoznawanie i rozróżnianie bodźców dźwiękowych. Obserwuje się u nich także lepsze kodowanie dźwięków mowy, co ułatwia procesy czytania i pisania. Ocena częstotliwościowych potencjałów wywołanych pozwala na monitorowanie zmian neuronalnych związanych z praktyką muzyczną.

Słowa kluczowe: słuchowe potencjały wywołane z pnia mózgu • muzyk • percepcja mowy • elektrofizjologia $・$ FFR

\section{Abbreviations}

ABR - Auditory Brainstem Response

FFR - Frequency Following Response

HINT - Hearing in Noise Test

MeSH - Medical Subject Headings

QuickSIN - Quick Speech in Noise test

VOT - Voice Onset Time

\section{Introduction}

Electrophysiological testing is an objective method of assessing and checking the integrity of auditory function and of gauging neuroplasticity [1]. The auditory brainstem response (ABR) provides diagnostic information about the pathway from the auditory periphery to the brainstem, and is routinely used in the clinic to assess hearing function $[2,3]$.

Traditionally, ABR responses are evoked by transient non-verbal stimuli. However, the use of the Frequency
Following Response (FFR) is a promising technique for investigating the temporal encoding of speech in the brainstem. Speech sounds are complex sounds with rich harmonic structure, dynamic amplitude modulations, and rapid spectrotemporal fluctuations. This complexity is represented by an exceptionally precise temporal and spectral neural code within the auditory brainstem [4].

The FFR consists of the response to a consonant-vowel syllable which can be analysed in terms of the vowel and consonant separately. The wave generated by this stimulus is composed of onset response peaks ( $\mathrm{V}$ and $\mathrm{A}$ ) representing the burst onset of the voiced consonant, whereas the later portions probably represent the offset of the onset burst or the onset of voicing (wave $\mathrm{C}$ ) and the offset of the stimulus (wave $\mathrm{O}$ ). The harmonic portion of the speech stimulus gives rise to the frequency-following response (FFR, waves $\mathrm{D}, \mathrm{E}$, and F). The difference between the response peaks $\mathrm{D}$, $\mathrm{E}$, and $\mathrm{F}$ corresponds to the wavelength of the fundamental frequency (F0), and a Fourier analysis of this portion of the response confirms a spectral peak at F0 and also at the first 
formant frequency (F1) $[5,6]$. Recent studies have shown that the FFR gives insights into the diagnosis of children with learning disabilities, temporal encoding of amplitude modulations, speech, tonal language processing skills, temporal acuity, and can assess neuroplastic changes in different populations, including musicians [2, 7-12].

Music is one of the most demanding of cognitive and neural challenges, which requires very precise and accurate timing of many actions, exact interval control of pitch not involved in language, and producing sound in many different ways [13]. Enhanced auditory perception in musicians is likely to result from auditory perceptual learning over years of training and practice. Musical experience affects brain structure, cortical activity, and auditory perception [14]. Musicians have different brain structures not only in the motor cortices, but also in the auditory cortices. In addition, musicians show different patterns of neural activation, such as stronger responses to simple, artificial tones, and heightened responses to the sound of their own instrument compared to other instruments [14].

\section{Method}

This study is based on a systematic review of the literature published between 2008 and 2015. Articles were selected from searches of Medline; US National Library of Medicine National Institutes of Health (PubMed); and the ISI Web of Science databases. When this study was started the terms most used to designate FFR were speechABR or Auditory Brainstem Response. However, the use the different terminologies could hinder descriptions of the procedure, and so the creator and principal investigator of the method, Dr Nina Kraus, suggested in 2017 the term Frequency Following Response (FFR). For this reason, for the definition of the research terms the broader term, speech ABR, was chosen. Keywords were restricted to English and accorded with the Medical Subject Heading terms (MeSH). They were: Musicians, Auditory Brainstem Response, Speech ABR, Speech Perception, and Frequency Following Response. The query terms were searched using the Boolean operator OR.

Two independent reviewers identified the studies. Discrepancies were resolved through discussion. The paper selection procedure followed the steps reported below (Figure 1).

\section{Inclusion criteria:}

(i) Articles published between 2008 and 2015

(ii) Original articles (a research report and not just a summary)

(iii) Musicians as the study sample

(iv) Studies using FFR as assessment.

\section{Exclusion criteria:}

(i) Experiments on animals

(ii) Case studies

(iii) Articles not published in English.

After the selection, the variables such as sample size, age, gender, native language, preliminary and complementary assessment, equipment, stimulus, objective, results, and conclusions were collected from each paper. The data extracted from the selected papers are presented in Table 1. In the table, data are presented according to the nomenclature used by the authors.

\section{Results}

Subjects aged 3-65 years were evaluated in the 11 articles [7-10, 12, 17-21, 23] selected. Sample sizes ranged from 14 to 87 subjects, with a total number of 421 subjects. There was a preference for females, totalling 95 (54\%) of the 176 subjects whose gender could be identified. However, in 5 articles it was not possible to identify the gender of the individuals [7,9,16-18]. Among the 11 articles selected, 8 were conducted at the Auditory Neuroscience Laboratory and Department of Communication Sciences at Northwestern University, USA [7-9, 12, 17-19, 22], two at the Purdue University, USA [21, 23], and one at the University of Memphis, USA [10]. The large number of studies from the same institution is due to the existence of FFR specialists at these places. However, the subjects who comprised each study were different from each other, and the studies were carried out at different times.

Of the 11 articles selected, a total of 9 (82\%) compared musicians and non-musicians [7, 10, 15-17, 19-22]. The classification criteria between each group was the number of years the subjects had had musical experience. However, three articles did not indicate the selection criteria for the control or study group $[10,16,18]$.

Among the articles selected, 9 presented a sample with normal hearing, absence of previous history of neurological or cognitive deficits, psychiatric disease, or learning difficulties. However, one reported a study of individuals with mild to moderate sensorineural hearing loss [15] and one used native speakers of English or Mandarin [23].

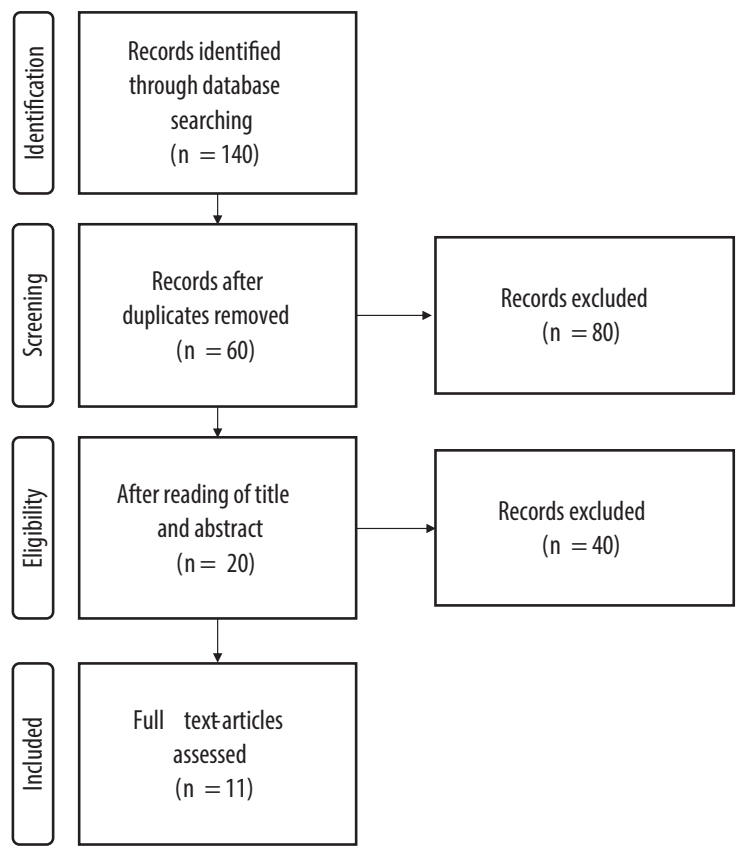

Figure 1. Flow-chart 
Table 1. Musicians and FFR assessment (2008-15)

\begin{tabular}{lccc}
\hline Article & No. & Sample (mean \pm SD) & Objectives \\
\hline Weiss 2015 & 1 & 14 young adults (8F; $28.7 \pm 3.2$ years) \\
& & Divided into Mu and NM & $\begin{array}{c}\text { To examine the intelligibility of auditory playbacks } \\
\text { of brainstem potentials recorded in human } \\
\text { listeners }\end{array}$
\end{tabular}

\begin{tabular}{|c|c|c|c|}
\hline Strait 2014 & 2 & $\begin{array}{c}76 \text { subjects aged } 3-30 \text { years, categorized as Mu and NM } \\
21 \text { preschoolers ( } 3-5 \text { years old) } \\
26 \text { school-aged children ( } 7-13 \text { years old) } \\
29 \text { adults (18-30 years old) }\end{array}$ & $\begin{array}{c}\text { To assess speech ABR, auditory, and visual } \\
\text { cognitive abilities in Mu and NM }\end{array}$ \\
\hline $\begin{array}{l}\text { Parbery- } \\
\text { Clark } 2013\end{array}$ & 3 & $\begin{array}{l}34 \text { middle-aged adults with mild or moderate sensorineural; } \\
\text { aged } 45-65(58 \pm 4) \text {. } \\
\text { SG: } 17 \text { Mu having started musical training before the age of } 9 \\
\text { CG: } 17 \text { NM with (a) } 11 \text { subjects having had no musical } \\
\text { training; (b) } 6 \text { having < } 5 \text { years of musical experience }\end{array}$ & $\begin{array}{c}\text { To determine whether similar advantages } \\
\text { could be observed in middle-aged adults with } \\
\text { hearing loss }\end{array}$ \\
\hline $\begin{array}{l}\text { Parbery- } \\
\text { Clark } 2012 \text { b }\end{array}$ & 4 & $\begin{array}{l}48 \text { middle-aged adults } 45-65(56 \pm 5) \\
\text { SG: } 23 \text { Mu having started musical training before the age of } 9 \\
\text { CG: } 25 \text { NM with (a) } 17 \text { subjects had no musical training; } \\
\text { (b) } 8 \text { subjects having < } 4 \text { years of musical experience }\end{array}$ & $\begin{array}{l}\text { To define the effects of musical experience } \\
\text { on subcortical responses to speech and } \\
\text { speech-in-noise perception in middle-aged adults }\end{array}$ \\
\hline $\begin{array}{l}\text { Parbery- } \\
\text { Clark } 2012\end{array}$ & 5 & $\begin{array}{l}50 \text { young adults (ages } 18-32,22 \pm 3.5 \text { ) } \\
\text { Gl: } 23 \mathrm{Mu}(15 \mathrm{~F}) \text { started musical training by the age of } 7 \\
\text { Gll: } 27 \mathrm{NM}(15 \mathrm{~F}),<3 \text { years of musical training }\end{array}$ & $\begin{array}{c}\text { To ask if musicians demonstrate greater } \\
\text { subcortical differentiation of speech syllables } \\
\text { that are distinguishable only by their second } \\
\text { formant trajectories }\end{array}$ \\
\hline
\end{tabular}

\begin{tabular}{|c|c|c|c|}
\hline $\begin{array}{l}\text { Parbery- } \\
\text { Clark } 2012 \text { c }\end{array}$ & 6 & $\begin{array}{l}50 \text { younger subjects (aged } 18-32 \text { years, } 23 \pm 4 \text { ) } \\
37 \text { older subjects (aged } 46-65,56 \pm 5 \text { ). } \\
\text { SG: } 46 \text { Mu (26 younger, } 20 \text { older) started musical training } \\
\text { < age of } 9 \\
\text { CG: } 41 \text { NM ( } 24 \text { younger, } 17 \text { older): } \\
\text { (a) } 27 \text { had no musical training (15 younger, } 12 \text { older); } \\
\text { (b) } 14 \text { (9 younger, } 5 \text { older) < } 3 \text { years of musical experience }\end{array}$ & $\begin{array}{c}\text { To verify whether musical experience offsets the } \\
\text { decline in neural precision that occurs during the } \\
\text { natural aging process }\end{array}$ \\
\hline $\begin{array}{l}\text { Bidelman } \\
2011\end{array}$ & 7 & $\begin{array}{c}11 \text { English-speaking Mu (4 F) } \\
11 \text { English-speaking NM (5 F) } \\
11 \text { native speakers of Mandarin Chinese (6 F) }\end{array}$ & $\begin{array}{l}\text { To determine if enhancements in subcortical } \\
\text { processing translate to improvements in the } \\
\text { perceptual discrimination of musical pitch }\end{array}$ \\
\hline
\end{tabular}

\begin{tabular}{llc}
\hline $\begin{array}{l}\text { Bidelman } \\
2011 \mathrm{~b}\end{array}$ & 8 & $11 \mathrm{Mu}(4 \mathrm{~F})>10$ years of continuous instruction on their \\
principal instrument & $\begin{array}{c}\text { To address whether this superiority is also present } \\
\text { at a subcortical stage of pitch processing }\end{array}$
\end{tabular}

11 NM (5 F) <1 year of formal music training

\begin{tabular}{|c|c|c|c|}
\hline $\begin{array}{l}\text { Anderson } \\
2010\end{array}$ & 9 & $\begin{array}{c}\text { Children with typical development } \\
\text { Children with language-based learning impairment } \\
\text { Young adults } \\
\text { Older adults } \\
\text { Auditory experts }\end{array}$ & \\
\hline $\begin{array}{l}\text { Parbery- } \\
\text { Clark } 2009\end{array}$ & 10 & $\begin{array}{c}31 \text { participants aged from } 19 \text { to } 30(23 \pm 3) \\
16 \text { Mu (10 F) with >10 years of instrumental practice } \\
15 \text { NM }(9 \mathrm{~F}) \text { with }<3 \text { years of musical training }\end{array}$ & $\begin{array}{l}\text { To investigate the effect of musical experience on } \\
\text { the neural representation of speech-in-noise }\end{array}$ \\
\hline $\begin{array}{l}\text { Musacchia } \\
2008\end{array}$ & 11 & $\begin{array}{l}26 \text { adults, } 14 \mathrm{~F}(25.6 \pm 4.1) \\
14 \mathrm{Mu},>10 \text { years of musical experience } \\
12 \mathrm{NM},<10 \text { years of musical experience }\end{array}$ & $\begin{array}{l}\text { To verify if musical training shapes the auditory } \\
\text { system in a coordinated manner or in disparate } \\
\text { ways at cortical and subcortical levels }\end{array}$ \\
\hline
\end{tabular}

Abbreviations: F, female; SD, standard deviation; Mu, musicians; NM, nonmusicians; PTA, pure tone audiometry; ABR, auditory brainstem response; PPVT, Peabody picture vocabulary test; WASI, Wechsler abbreviated scale of intelligence; CAT, Colorado assessment tests; IMAP, IHR multicentre battery for auditory processing; TONI, test of nonverbal intelligence; 


\begin{tabular}{|c|c|c|}
\hline Assessments & Results & Conclusion \\
\hline $\begin{array}{l}\text { PTA, speech ABR, speech } \\
\text { classification task }\end{array}$ & $\begin{array}{l}\text { Naive listeners' behavioral classification of } \\
\text { "sonifications" as faster and more categorical when } \\
\text { evaluating brain responses recorded in individuals } \\
\text { with extensive musical training versus those } \\
\text { recorded in nonmusicians }\end{array}$ & $\begin{array}{l}\text { Stronger behaviorally relevant speech cues } \\
\text { in musicians' neural representations and } \\
\text { demonstrate causal evidence that superior } \\
\text { subcortical processing creates a more } \\
\text { comprehensible speech signal }\end{array}$ \\
\hline $\begin{array}{c}\text { PTA, speech ABR, click ABR } \\
\text { Preschoolers: PPVT } \\
\text { School-aged: WASI, TONI, CAT, IMAP } \\
\text { Adults: TONI, CAT, IMAP }\end{array}$ & $\begin{array}{c}\text { Musicians exhibit enhanced neural differentiation } \\
\text { of stop consonants early in life and with as little as } \\
\text { a few years of training }\end{array}$ & $\begin{array}{l}\text { The subcortical processing enhancements are } \\
\text { engendered by strengthened cognitive control } \\
\text { over auditory function in musicians }\end{array}$ \\
\hline $\begin{array}{l}\text { PTA, speech ABR, click ABR, HINT } \\
\text { WASI, SSQ, WJ III }\end{array}$ & $\begin{array}{c}\text { Musicians with hearing loss have a greater ability } \\
\text { to hear in noise, more robust subcortical encoding } \\
\text { of sound, more resilient neural responses to speech } \\
\text { in the presence of background noise relative to } \\
\text { nonmusicians }\end{array}$ & $\begin{array}{l}\text { The musician advantage for perceiving } \\
\text { speech in noise persists in a hearing-impaired } \\
\text { population by adaptively strengthening } \\
\text { underlying neural mechanisms for } \\
\text { speech-in-noise perception }\end{array}$ \\
\hline $\begin{array}{l}\text { PTA, click ABR, and speech ABR } \\
\text { IQ Test: WASI }\end{array}$ & $\begin{array}{l}\text { Musicians have enhanced neural encoding of } \\
\text { speech in quiet and noisy settings, including faster } \\
\text { neural response timing, higher neural response } \\
\text { consistency, more robust encoding of speech } \\
\text { harmonics, and greater neural precision }\end{array}$ & $\begin{array}{l}\text { Musical experience provides perceptual } \\
\text { benefits in aging population by strengthening } \\
\text { the underlying neural pathways necessary } \\
\text { for the accurate representation of important } \\
\text { temporal and spectral features of sound }\end{array}$ \\
\hline $\begin{array}{l}\text { PTA, click ABR, Speech ABR /ba/, } \\
\text { /da/, and /ga/ } \\
\text { IQ test: TONI } \\
\text { QuickSIN }\end{array}$ & $\begin{array}{l}\text { Musicians demonstrate enhanced subcortical } \\
\text { discrimination of closely related speech sounds }\end{array}$ & $\begin{array}{l}\text { A musician-enhancement for the neural } \\
\text { processing of speech and reveals a biological } \\
\text { mechanism contributing to musicians' } \\
\text { enhanced speech perception in noise }\end{array}$ \\
\hline $\begin{array}{l}\text { PTA and speech ABR } \\
\text { Younger: TONI } \\
\text { Older: WASI }\end{array}$ & $\begin{array}{c}\text { Musicians show less age-related neural delays } \\
\text { than nonmusicians. Younger and older musicians } \\
\text { have equivalent neural timing except for the onset } \\
\text { response. } \\
\text { Older nonmusicians show an age-related shift in } \\
\text { neural response timing for both the onset and } \\
\text { transition }\end{array}$ & $\begin{array}{l}\text { The musical experience protects against } \\
\text { age-related degradation in neural timing, } \\
\text { highlighting the modifiable nature of } \\
\text { these declines }\end{array}$ \\
\hline $\begin{array}{l}\text { Speech ABR with triad arpeggios } \\
\text { as stimuli }\end{array}$ & $\begin{array}{l}\text { Both musicians and Chinese had stronger } \\
\text { brainstem representation of the defining pitches of } \\
\text { musical sequences. } \\
\text { Neither Chinese nor non-musicians were able to } \\
\text { discriminate subtle changes in musical pitch with } \\
\text { the same accuracy as musicians }\end{array}$ & $\begin{array}{l}\text { The sensory-level enhancement of musical } \\
\text { pitch information yields cognitive-level } \\
\text { perceptual benefits only when that information } \\
\text { is behaviorally relevant to the listener }\end{array}$ \\
\hline $\begin{array}{l}\text { Speech ABR with triad arpeggios } \\
\text { as stimuli }\end{array}$ & $\begin{array}{l}\text { Musicians had faster neural synchronization } \\
\text { and stronger brainstem encoding for defining } \\
\text { characteristics of musical sequences. } \\
\text { Nonmusicians had relatively strong representation } \\
\text { for major/minor chords but showed diminished } \\
\text { responses for detuned chords }\end{array}$ & $\begin{array}{c}\text { Perceptually salient aspects of musical pitch are } \\
\text { not only represented at subcortical levels but } \\
\text { that these representations are also enhanced } \\
\text { by musical experience }\end{array}$ \\
\hline Speech ABR, HINT, QuickSIN & $\begin{array}{l}\text { Children and adults with poor SIN perception } \\
\text { have deficits in the subcortical spectrotemporal } \\
\text { representation of speech. } \\
\text { Auditory expertise, as engendered by musical } \\
\text { training, provides both behavioral and neural } \\
\text { advantages for processing speech in noise }\end{array}$ & $\begin{array}{l}\text { The cABR provides a clinically applicable } \\
\text { metric for objective assessment of individuals } \\
\text { with SIN deficits and for determination of } \\
\text { the biologic nature of disorders affecting } \\
\text { SIN perception }\end{array}$ \\
\hline $\begin{array}{l}\text { Speech ABR quiet and in noise, } \\
\text { click ABR, HINT }\end{array}$ & $\begin{array}{l}\text { Musicians have a more robust subcortical } \\
\text { representation of the acoustic stimulus in the } \\
\text { presence of noise, faster neural timing, enhanced } \\
\text { representation of speech harmonics, and less } \\
\text { degraded response morphology in noise. } \\
\text { Musicians have better performance on HINT than } \\
\text { nonmusician controls }\end{array}$ & $\begin{array}{l}\text { Musical experience limits the negative } \\
\text { effects of competing background noise, } \\
\text { thereby providing the first biological evidence } \\
\text { for musicians' perceptual advantage for } \\
\text { speech-in-noise }\end{array}$ \\
\hline $\begin{array}{c}\text { PTA, speech ABR, EEG data } \\
\text { Seashore's Test of Musical Talents } \\
\text { and MAT-3 }\end{array}$ & $\begin{array}{c}\text { Musical training promotes plasticity throughout the } \\
\text { auditory and multisensory pathways. This includes } \\
\text { encoding mechanisms that are relevant for musical } \\
\text { sounds as well as for the processing of linguistic } \\
\text { cues and multisensory information }\end{array}$ & $\begin{array}{c}\text { Neural representations of pitch, timing and } \\
\text { timbre cues, and cortical response timing } \\
\text { are shaped in a coordinated manner, and } \\
\text { indicate corticofugal modulation of subcortical } \\
\text { afferent circuitry }\end{array}$ \\
\hline
\end{tabular}

SG, study group; CG, Control Group; HINT, hearing in noise test; SSQ, speech, spatial, and qualities of hearing questionnaire; WJ III, Woodcock Johnson III test of cognitive abilities; IQ, intelligence quotient; QuickSIN: quick speech in noise test; EEG, electroencephalography; MAT-3, Colwell's musical achievement test 
From early on in life, musicians appear to have better subcortical processing for speech and better specific auditory and cognitive abilities. The subcortical processing enhancements of musicians are engendered by stronger cognitive control over auditory function [16].

Parbery-Clark et al. [19] found that musicians demonstrate greater subcortical discrimination of speech syllables distinguishable only by their second formant trajectories (/ba/, /da/, /ga/). In addition to having greater neural discrimination for these speech syllables, musicians outperform nonmusicians on the Quick SIN test (Quick Speech in Noise Test).

Musical experience promotes plasticity along the auditory and multisensory pathways. This includes neural representation of pitch, timing, timbre cues, and cortical response timing that are relevant for musical sounds as well as for the processing of linguistic cues and multisensory information.

In older people, research finds that the perception of consonants is compromised, unlike the perception of vowels, which is minimally affected by age. Delay in the neural response to the formant transition in the syllable /da/ (30-70 ms over the 4 peaks) has been reported. In musicians, regardless of their age, the response time was the same for the formant transition, whereas for older non-musicians there was a much greater delay [7]. At the same time, middle-aged musicians with hearing loss have better listening skills compared to non-musicians, with more robust subcortical encoding of sound and more resilient neural responses to speech in the presence of background noise [15].

Difficulty of hearing in background noise is a common complaint in young and older populations. Musicians have a neural advantage in distinguishing speech sounds in noise. In noisy environments, middle-aged subjects with normal hearing had enhanced neural encoding of speech related to their musical experience. This also includes faster neural response timing, higher neural response consistency, more robust encoding of speech harmonics, and greater neural precision [17].

The effect of musicality in aging is some protection against age-related degradation in neural timing and neural mechanisms, attenuating the effects of aging on the neural coding of speech stimuli $[7,17]$. This brings an advantage for perceiving speech in noise and shows a strengthening of underlying neural mechanisms in older musicians [15]. In another piece of research seeking to quantify the effects of noise on the neural response time, an FFR was performed over three regions: (i) the consonant; (ii) the transition between the consonant and the vowel; and (iii) the vowel. The musicians' responses had larger amplitudes and decreased latencies [16].

The stronger and faster responses in musicians are related to better speech perception in noise as measured by the Hearing in Noise Test (HINT) [17, 19, 21]. The findings of Parbery-Clark et al. [21] reinforce that musicians perform better in HINT than non-musicians, including a more robust subcortical representation of the acoustic stimulus in the presence of noise and less degraded response morphology in noise.
Musical experiences provide children and adults with poor speech perception a degree of behavioral and neural advantage for speech processing in noise [18]. This population also presents deficits in the temporal representation of speech.

Rather than using classic speech material, new stimuli have been devised. Weiss and Bidelman [10] analysed neural responses to digital audio samples, comparing the musicality effects of neurophysiological coding. The responses of individuals with extensive musical training were more rapid compared to non-musicians and categorical when analysed with acoustic stimulation. The study highlights how differences in subcortical processing affect speech perception and suggests that plasticity depends on brain experience [10].

The subcortical processing of musicians and non-musicians can also be studied in terms of the native language of each speaker. Bidelman [20,23] studied the responses of musicians and non-musicians who speak English and Mandarin Chinese to musical stimuli. The responses of native Mandarin speakers were clearer and more robust than non-musician English speakers. This suggests that experience with linguistic pitch translates to nonlinguistic domains.

FFR evaluations show that individuals with both linguistic and musical experience produce a change in cerebral synapses and have a greater neural representation of speech sounds. However, only individuals with musical experience process sound perceptually [19].

\section{Discussion}

Despite language and music being systems with different representations, structures, and utilities, they both share the same basic element, the temporal organisation of an acoustic signal. This is the starting point for perception of speech and music [24].

The FFR arose from a need to complement the results of traditional neurophysiological assessments. In addition, it allows an understanding of how the brainstem functions in perceiving sounds. The majority of studies have targeted the adult population, a choice possibly due to the better consistency of adult responses to the FFR [2]. However, for this review we found two normative studies of FFRs in children $[25,26]$.

There are still a dearth of studies involving children with musical experience, however one important article [9] showed that children with musical experience had better auditory attention, larger working memory, improvement in voice onset time (VOT) processing, and duration of syllable and speech segmentation skills. Thus, children with musical experience are better able to distinguish the place of articulation (the onset portion of the FFR), which can help in later academic life due to improvements in reading and linguistic skills. It has been found that a short period of musical auditory stimulation improves the perception of sounds and especially the auditory discrimination of verbal sounds. These changes can be observed in FFR values [9]. 
FFR records show gender differences, where female subjects have faster coding and better phonetic analysis [27]. Similarly, women present a faster and better response to the transient portion of a stimulus compared to men [28].

Despite a diversity in the populations analysed, the results generally point to the benefits of long-term musical training, such as improvements to the ability to detect small differences between frequencies [19].

Musical training alters subcortical sensory coding of dynamic tone contours, especially for complex and new stimuli [14]. This subcortical neural representation of speech and musical stimuli correlates positively with the amount of musical training received, suggesting that this fact is shaped by experience rather than being an innate ability [29].

To build auditory acuity, musicians actively engage topdown mechanisms, where subcortical sensory processes interact dynamically with cortical processes, such as memory, attention, and multisensory integration, to shape the response of the perceptual system to speech and music, transmitting melodic and semantic or pragmatic information [14].

Children and adult musicians have a more robust and accurate neural response for speech signals (formant of the vowel), more adaptive sound processing, and more precise neural processing for acoustically similar sounds compared to non-musicians [24]. These auditory system enhancements contribute to linguistic advantages such as hearing in noise and reading skills [30].

In musicians, FFR recordings in the presence of competing noise show that their high cerebral specificity to sound means a less degraded FFR response to vowels compared to responses from non-musicians [20].

Good auditory temporal resolution is important for understanding speech in noise for listeners with normal hearing, hearing aid users, individuals with cochlear implants, and language disorder groups [13]. Musical training is beneficial because it helps in reducing background noise, allowing a musician to maintain concentration and focus [21, 23]; this could be the biological explanation for the better quality of perception of speech in noise by musicians [21].
Musical training modifies the central auditory nervous system through neural plasticity, causing significant improvements in the structures and auditory pathways throughout the system [22]. These beneficial changes are long-lasting, and may affect other areas of auditory information processing, not only those involved in the perception of speech sounds [16].

Neuroimaging studies confirm that playing music requires a strong coupling of perception and action mediated by sensory, motor, and multimodal integration regions distributed throughout the brain [32].

The benefits of exposure to music can lead to improvements in scholastic performance (math, reading, vocabulary, syntax, and visuospatial and motor skills). Auditory stimulation can revitalise and strengthen brain connections and this process seems to assist in healthier aging.

As described, intensive musical training can lead to modifications in brain structure and function. Recent research has demonstrated that training-induced plasticity is not restricted to the developing brain, but that intensive skill learning in adulthood can also lead to plastic changes. Even for older adults, skill learning appears to preserve gray and white matter structures during the normal ageing process when the brain generally undergoes substance loss [33, 34].

The analysis of these studies showed that musical experience throughout life is similar to an auditory training program. In addition, this auditory training is long-term, since musical individuals rarely interrupt their involvement with music. Instead, musicians tend to improve their skills, such as learning new musical instruments, thereby amplifying and strengthening neural circuits. New research is needed in order to understand how improvements in neural circuitry are built and sustained [7].

\section{Conclusion}

Studies have shown that musical learning benefits development in a global way. The detection, recognition, and discrimination abilities of sound stimuli are processed more accurately and effectively in individuals with some type of musical learning. This improvement also occurs in the encoding of speech sounds, thus helping in literacy. FFR recordings allow neural changes derived from musical training to be monitored.

\section{References}

1. Sanju HK, Kumar P. Enhanced auditory evoked potentials in musicians: A review of recent findings. Journal of Otology, 2016; 11(2): 63-72.

2. Sanfins M, Colella-Santos M. A review of the Clinical Applicability of Speech-Evoked Auditory Brainstem Responses. J Hear Sci, 2016; 6(1): 9-16.

3. Sanfins M, Skarzynski P, Colella-Santos MF. Speech-evoked brainstem response: In: Hatzopoulos, S. Advances in Clinical Audiology. IntechOpen, 2017: 823-778.

4. Nada NM, Kolkaila EA, Gabr TA, El-Mahallawi TH. Speech auditory brainstem response audiometry in adults with sensorineural hearing loss. Egyptian J Ear Nose Throat Allied Sci, 2016; 17(2): 87-94.

Journal of Hearing Science · 2019 Vol. 9 • No. 2
5. Sinha SK, Basavaraj V. Speech evoked auditory brainstem responses: a new tool to study brainstem encoding of speech sounds. Indian J Otolaryngol Head Neck Surg, 2010; 62(4): 395-9.

6. Skoe E, Kraus N. Auditory brain stem response to complex sounds: a tutorial. Ear Hear, 2010; 31(3): 302-24.

7. Parbery-Clark A, Anderson S, Hittner E, Kraus N. Musical experience offsets age-related delays in neural timing. Neurobiol Aging, 2012; 33(7): 1483.e1-4.

8. Parbery-Clark A, Strait DL, Hittner E, Kraus N. Musical training enhances neural processing of binaural sounds. J Neurosci, 2013; 33(42): 16741-7. 
9. Strait DL, O'Connell S, Parbery-Clark A, Kraus N. Musicians' enhanced neural differentiation of speech sounds arises early in life: developmental evidence from ages 3 to 30. Cereb Cortex, 2014; 24(9): 2512-21.

10. Weiss MW, Bidelman GM. Listening to the brainstem: Musicianship enhances intelligibility of subcortical representations for speech. J Neurosci, 2015; 35(4): 1687-91.

11. Sanfins M, Borges L, Ubiali T, Colella-Santos M. Speech-evoked auditory brainstem response in the differential diagnosis of scholastic difficulties. Braz J Otorhinolaryngol, 2017; 83(1): 112-6.

12. Musacchia G, Strait D, Kraus N. Relationships between behavior, brainstem and cortical encoding of seen and heard speech in musicians and non-musicians. Hear Res, 2008; 241(1-2): 34-42.

13. Kumar P, Sanju HK, Nikhil J. Temporal resolution and active auditory discrimination skill in vocal musicians. Int Arch Otorhinolaryngol, 2016; 20(4): 310-4.

14. Kraus N, Skoe E, Parbery-Clark A, Ashley R. Experience-induced malleability in neural encoding of pitch, timbre, and timing. Ann N Y Acad Sci, 2009; 1169: 543-57.

15. Rakszawski B, Wright R, Cadieux JH, Davidson LS, Brenner C. The effects of preprocessing strategies for pediatric cochlear implant recipients. J Am Acad Audiol, 2016; 27(2): 85-102.

16. Parbery-Clark A, Anderson S, Kraus N. Musicians change their tune: how hearing loss alters the neural code. Hear Res, 2013; 302: 121-31.

17. Parbery-Clark A, Anderson S, Hittner E, Kraus N. Musical experience strengthens the neural representation of sounds important for communication in middle-aged adults. Front Aging Neurosci, 2012; 4: 30.

18. Anderson S, Kraus N. Sensory-cognitive interaction in the neural encoding of speech in noise: a review. J Am Acad Audiol, 2010; 21(9): 575-85.

19. Parbery-Clark A, Tierney A, Strait DL, Kraus N. Musicians have fine-tuned neural distinction of speech syllables. Neurosci, 2012; 219: 111-9.

20. Parbery-Clark A, Tierney A, Strait DL, Kraus N. Musicians have fine-tuned neural distinction of speech syllables. Neuroscience. 2012;219:111-9.

21. Bidelman GM, Krishnan A, Gandour JT. Enhanced brainstem encoding predicts musicians' perceptual advantages with pitch. Eur J Neurosci, 2011; 33(3): 530-8.
22. Parbery-Clark A, Skoe E, Kraus N. Musical experience limits the degradative effects of background noise on the neural processing of sound. J Neurosci, 2009; 29(45): 14100-7.

23. Bidelman G, Gandour J, Krishnan A. Musicians and tone-language speakers share enhanced brainstem encoding but not perceptual benefits for musical pitch. Brain Cognition, 2011; 77(1): $1-10$.

24. Asaridou SS, McQueen JM. Speech and music shape the listening brain: evidence for shared domain-general mechanisms. Front Psychol, 2013; 4: 321.

25. Sanfins MD, Borges LR, Ubiali T, Donadon C, Hein TAD, Hatzopoulos S, et al. Speech-evoked brainstem response in normal adolescent and children speakers of Brazilian Portuguese. Int J Pediatr Otorhinolaryngol, 2016; 90: 12-9.

26. Russo N, Nicol T, Musacchia G, Kraus N. Brainstem responses to speech syllables. Clin Neurophysiol, 2004; 115: 2021-30.

27. Ahadi M, Pourbakht A, Jafari AH, Shirjian Z, Jafarpisheh AS. Gender disparity in subcortical encoding of binaurally presented speech stimuli: an auditory evoked potentials study. Auris Nasus Larynx, 2014; 41(3): 239-43.

28. Krizman J, Skoe E, Kraus N. Sex differences in auditory subcortical function. Clin Neurophysiol, 2012; 123(3): 590-7.

29. Musacchia G, Sams M, Skoe E, Kraus N. Musicians have enhanced subcortical auditory and audiovisual processing of speech and music. Proc Natl Acad Sci USA, 2007; 104(40): 15894-8.

30. Lametti DR, Rochet-Capellan A, Neufeld E, Shiller DM, Ostry DJ. Plasticity in the human speech motor system drives changes in speech perception. J Neurosci, 2014; 34(31): 10339-46.

31. Bidelman GM, Alain C. Musical training orchestrates coordinated neuroplasticity in auditory brainstem and cortex to counteract age-related declines in categorical vowel perception. J Neurosci. 2015;35(3):1240-9.

32. Klein C, Liem F, Hänggi J, Elmer S, Jäncke L. The "silent” imprint of musical training. Hum Brain Mapp. 2016;37(2): 536-46.

33. Reybrouck M, Brattico E. Neuroplasticity beyond sounds: neural adaptations following long-term musical aesthetic experiences. Brain Sci, 2015; 5(1): 69-91.

34. Reybrouck M, Vuust P, Brattico E. Music and brain plasticity: how sounds trigger neurogenerative adaptations. In: Chaban V, editor. Neuroplasticity: Insights of Neural Reorganization. Croatia: IntechOpen; 2018. 